\title{
Determinants of Systematic Risk : Empirical Evidence from Shariah Compliants Firms Listed on Bursa Malaysia
}

\author{
Mohamad Nizam Jaafar ${ }^{\mathrm{a}}$, Amirul Afif Muhamat ${ }^{\mathrm{b}}$, Mohd Faizal Basri ${ }^{\mathrm{c}}$, \\ Sharifah Faigah Syed Alwi ${ }^{\text {d }}$ \\ a,d Arshad Ayub Graduate Business School, Universiti Teknologi MARA, 40450 Shah Alam, Selangor, \\ Malaysia \\ ${ }^{\mathrm{b}}$ Faculty of Business Management, Universiti Teknologi MARA, 40450 Shah Alam, Selangor, Malaysia \\ ${ }^{c}$ Faculty of Management and Economics, Universiti Pendidikan Sultan Idris, 35900 Tanjong Malim, Perak \\ Malaysia \\ Corresponding Author: mnizam7520@uitm.edu.my
}

To cite this article (APA): Jaafar, M. N., Muhamat, A. A., Basri, M. F., \& Syed Alwi, S. F. (2020). Determinants of Systematic Risk : Empirical Evidence from Shariah Compliants Firms Listed on Bursa Malaysia. International Business Education Journal, 13(1), 71-82. https://doi.org/10.37134/ibej.vol13.1.6.2020

To link to this article: https://doi.org/10.37134/ibej.vol13.1.6.2020

\begin{abstract}
This paper is aimed at advancing empirical indications on micro variable factors determining systematic risk in Shariah complaints firms listed on Bursa Malaysia. This paper also attempts to identify whether the Shariah compliant firms are showing the same micro variables factors that determine systemic risk. The systematic issues have become the main concern to many related parties such as policy makers, investors and stakeholders as systematic risk is unable to be removed through diversification. Shariah compliant firms have their own unique systematic risk owing to their difference in business philosophy. A hypothesis between the relationship of the firms-specific micro variable factors and systemic risk are established on foregoing studies and theoretical framework respectively, and analyzed using the Fixed Effects Model tested on the data from 80 listed companies covering a period from 2009 to 2018. The results show that leverage and growth are the most significant factors of the systematic risk of Shariah compliant firms. Therefore, high leverage and growth firms are considered to be high risk for investment in Malaysia capital market.
\end{abstract}

\section{Keywords:}

Shariah, Systematic risk, Islamic capital market, panel data, fixed effect model

\section{INTRODUCTION}

Risk has major impact on one and all, from individuals to firms and governments. Nevertheless, the foremost attention of this study is the risk encountered by the Shariah compliant firms in the Malaysian capital market. In general, the entire firms in different economic sectors are exposed to multiple types of risk in their operation, including market risk, credit risk, operational risk, liquidity risk, equity investment risk and compliance risk respectively. Furthermore, Shariah compliant companies have an additional type of risk that is specific to their nature of business which is the Shariah compliance risk (Ismail, 2010). Despite of in elevation level of risk turns into higher return, firms need to preserve equitable balance between risk and return (Biase and Apolito, 2012). A good firm is not exclusively focusing on profit and growth but also implementing a good risk management system (Chiou $\& \mathrm{Su}, 2007)$ 
The level where all revenues for a business deviate from the expected return of the investment is a quantity of its risk. The best known aspect which calculated the risk related with monetary choice is systematic risk. Beta is used to estimate Systematic risk. Beta factor has a essential part as it attribute to linking among firm decisions and stock market. Beta is a degree of the variations of a security in association to the market. Beta is applied in the Capital Asset Pricing Model (CAPM), a model that estimates the expected return of an asset based on its beta and expected market returns. The CAPM and the concept of beta as a measurement of systemic risk have several practical uses in portfolio management. CAPM offers a foundation for a very modest passive portfolio approach. Diversified holding of risky assets based on the sizes of market portfolio and combination of this portfolio with the riskfree asset accomplishes an anticipated risk return combination. Furthermore, the CAPM is also applied in the calculating of the discount rate in valuation models of the firms (Kumar, Aleemi and Ali, 2015)

Determinants of systematic risks have been broadly deliberated in financial literature and are considered as one of the most motivating issues in stock market studies (Logue and Merville ; 1972, Breen and Lerner; 1973, Mao ;1976 , Gu and Kim ; 2002 , Hooy \& Lee ; 2010 , Hooy \& Lee; 2012). Albeit the researches covered numerous forms of companies and industries in different country settings, they are still inconclusive. Reciprocated conclusion has not been obtained regarding the definite variables that can be considered as the factors influencing systematic risk (Ibrahim \& Haron, 2016). In addition, most studies do not deal with systemic risk in Shariah complaint firms market of Malaysia. This paper aims at escalating the evidence arising from the existing literature by studying the main factors that determint the systemic risk among the shariah compliant firms in Malaysia. More specifically, present estimates are based on accounting and market panel data on Malaysia listed shariah compliant companies that were publicly traded on the Bursa Malaysia from 2009 to 2018. Six financial ratios were chosen as the respective proxy for the independent variables in determinanting of the factors of systemic risk among shariah compliant firms namely: (1) Size, (2) profitability, (3) liquidity, (4) leverage, (5) growth, (6) operating efficiency. The rationale for the selection of variables was essentially based on market model (Sharpe, 1963); financial theory and investors' intuition (Beaver et al. ; 1970, Rosenberg and McKibben ; 1973, Blume Model ; 1971, Lev and Kunitzky ;1974 , Bildersee ; 1975, Beaver and Manegold ; 1975, Chen et al. ; 1986 , Martikainen ; 1991, McMillan ; 2001 , Hong and Sarkar ; 2007 , Iqball and Shah ; 2011, Dimson Fowler Theory, Dimson ; 1979, Husin \& Wong;2016 )

There are Shariah compliant and non-Shariah compliant companies operating in the same economic setting. Accordingly, Malaysian capital market can be separated into two groups namely the conventional capital market and Islamic capital market respectively. Since September 2016, the Islamic capital market has made of $61 \%$ of the entire Malaysian capital market (The Star, 2016). Islamic capital market supports the nation's economic growth by providing a platform specifically for Shariah compliant companies from various sectors to obtain financing and expand their businesses. The Shariah Advisory Council (SAC) of the Securities Commission Malaysia will release an updated list of Shariah compliant securities twice a year, which are on May and November. As at 21 November 2016, 74\% (672 out of 904) of securities listed on Bursa Malaysia are Shariah compliant (Securities Commission Malaysia, 2016).

A study dedicated to shariah compliant stock market on systemic risk would be engaging not limited to the analysts and researchers around the globe but also to the 
practioners that consists of investors and corporate managers. This paper, thus, enriched the literature by exploring the factors of systemic risk in the Islamic capital market of Malaysia. The policy implication section of this paper will illuminate the implication of findings in greater detail.

\section{LITERATURE REVIEW}

Numerous of the empirical studies apply multiple regressions with beta being considered as dependent variables and firms' financial ratios are used as independent variables to determine factor of systematic risk. (Beaver et al., 1970; Gu \& Kim, 2002; Kim, Gu, \& Mattila, 2002; Lee and Jang, 2006 Lee \& Jang, 2007; Al-Qaisi, 2011; Iqbal \& Ali Shah, 2012; Biase \& D‘Apolito, 2012; Alaghi, 2013; Hariati \& Suci, 2013; Iqbal, Iqbal, \& Khan, 2015; Kumar, Aleemi, \& Ali, 2015; Li, 2016). Amongst the initial research that relate to systematic risk and financial variables, Beaveret et. al (1970) found a significant relationship between beta (systematic risk) financial variables namely leverage and liquidity. For financial institutions, systematic risk and bank size have a positive relationship (Biase and D'Apolito ; 2012). This is also supported by the study conducted by Iqbal and Ali Shah (2012), who performed a study on 93 non-financial institutions in Kerachi and also find a positive correlation with beta and size. Nevertheless, a different finding was revealed on a study conducted by Lee et al. (2015) who focused on identifying the determinants of systematic risk in US-based online travel agency that were listed on NYSE from 2001 to 2010. The results demonstrate that as size of company increases, its systematic risk decreases. The possible outcome is due to the benefit of economies of scale. Large firms are assumed to do business in an effective way, thus they have more economical power in the market in contrast to smaller firms, which results in their having lower systematic risk. Profitability refers to the ability of a business to generate returns. Return on Assets (ROA) is the most frequent proxy chosen by researchers to represent profitability of a firm. Studies also show a negative relationship between profitability and risk or beta (Mear and Firth , 1988). The reason is with higher profits, firms are less likely to face bankruptcy. Nonetheless, there are also preceding studies which have established that profitability significantly correlates to systematic risk in a positive way. (Iqbal and Ali Shah ; 2012, Alaghi ; 2013, and Iqbal et al. ; 2015). Their results proposed that firm that earned higher revenue inclines to be exposed to greater systematic risk. The reason behind this result is by having higher risk, firms are compensated with higher yields as supported by the risk-return trade off principle. Profitable firms also usually have more aggressive business approaches, therefore this brings them to higher systematic risk.

Further, numerous studies that employed Earning per Share (EPS) or Return on Equity (ROE) as the proxy of profitability and have positive relationship finding. Hariati and Suci (2013) used both ROA and ROE as the proxy for profitability and both shows positive affect systematic risk of the stocks of 28 Islamic companies listed on the Indonesian Stock Exchange. Furthermore, Kumar et al. (2015) claimed that EPS and systematic risk of banks in Pakistan are positively correlated. Financial firms earned more profit when they were exposed to higher credit risk, thus leading to higher systematic risk.

Liquidity shows the ability of a firm to meet its obligations. Most of the studies, use quick ratio as the proxy used for liquidity. A Majority of the findings show liquidity has significant negative impact on the systematic risk of the firms. This is in line with the studies done by Beaver et al.(1970) Logue and Merville (1972), Moyer and Charlfield (1983), Mear 
and Firth (1988), Gabriel (2005), Iqbal and Ali Shah (2012), Biase and D'Apolito (2012), Alaghi (2013), Kumar et al. (2015), Iqbal et al. (2015) and Lee et al. (2015). Firms with high liquidity are expected to have less exposure to systematic risk as they have sufficient capital to meet their short-term obligations.

The most frequently used proxy to signify leverage is debt ratio, which is stated as the ratio of total debts to total assets. Most of the empirical results show same relationship between leverage and systematic risk namely studies conducted by Kim et al. (2002), Gabriel (2005), Lee and Jang (2007), Hooy and Lee (2010) and Alaghi (2013). All of their findings show positive correlation between systematic risk and leverage, in line with theory that advocate higher level of leverage causes to higher systematic risk.

Another financial variable is called growth of a firm which is measured through its growth of revenue or asset respectively. Past empirical studies relate firm's growth with the annual percentage variation in earnings before interest and taxes (EBIT). Gabriel (2005) and Lee and Jang (2007) claimed a negative relationship between growth and systematic risk. They claimed that a firm with decent growth rate in EBIT has better prospects for expansion. Therefore, the market will perceive it as less risky. As a result, the market is willing to buy its stock at higher price as they have confident with the firm to earned higher revenue in the near prospect. Nevertheless, there are also findings that show a negative relationship with beta (Lee and Jang ; 2007, and Borde ; 1998). This is due to investor value growth opportunities. The firms that record high growth always reflected in their high stock prices while firms with small growth may have their stock prices more volatile.

Operating efficiency relates to the firm's capability to generate income from their assets. It reflects the effectiveness of the firms to utilize their assets to earn income. The proxy that is commonly used for operating efficiency is the total assets turnover ratio (Kim, $\mathrm{Gu}$, \& Mattila; 2002). Most of the empirical evidences show that operating efficiency significantly impacts systematic risk of companies in negative way. This means that as operating efficiency increases, the systematic risk decreases as implied by the findings of $\mathrm{Gu}$ and Kim (2002), Gabriel (2005), Iqbal and Ali Shah (2012) and Alaghi (2013). Gu and Kim (2002) proposed that companies with higher operating efficiency will be able to generate higher profits and accordingly reduce the probability of failure and lower systematic risk. However, the studies conducted by Iqbal et. Al (2015) found significant evidences that operating efficiency has a positive impact on the company's systematic risk.

The review of mentioned empirical evidences reveals that size, leverage, profitability, growth, liquidity and operating efficiency are the major determinants of systemic risk for companies traded on stock markets. Therefore, this study will adopt this model for the factors of systematic risk among the shariah compliant firms listed on Bursa Malaysia.

\section{EMPIRICAL METHODOLOGY AND MEASUREMENT OF VARIABLES}

The methodology will explain in term of the model specification, sources of the data, the proposed of hypothesis, recognize all of the variables and the quantification as well as the econometric model. Descriptive cum analytical research design were engaged in order to carry out of this study. Descriptive design were used as a primarily for conceptulizations of the matter. To analyse the results and data, analytical research design was engaged. The 
sample in this study consisted of 80 listed firms or company under shariah compliance. Which is taken out from both Ace Market and Bursa Malaysia from the years 2009 to 2018.

Any company that being delisted as non shariah compliant is not included from our sample. In order to inspect the relationship between company specific financial factors and systematic risk, Statistical Package for Social Science (SPSS) 20 was develop based on empirical findings :

a. Emprical Model - Multiple Regression

$$
\text { Beta }_{i t}=\beta_{0}+\beta_{1} \text { Siz }_{i t}+\beta_{2} \text { Pro }_{i t}+\beta_{3} L I Q_{i t}+\beta_{4} L a v_{i t}+\beta_{5} \text { Gro }_{i t}+\beta_{6} E f i_{i t}+\varepsilon_{i t}
$$

Where:

Betait $=$ Systematic risk firm $i$ at time $t$.

Sizit $=$ Size of firm $i$ at time $t$.

Proit $=$ Profitability of firm $i$ at time $t$.

LIQit $=$ Liquidity of firm $i$ at time $t$.

Groit $=$ Growth of firm $i$ at time $t$.

Efiit $=$ Operating efficiency of firm $i$ at time $t$.

$\beta_{0} \quad=$ common $y$-intercept.

$\varepsilon_{i t} \quad=$ stochastic error term of firm $i$ at time $t$.

$\varepsilon_{i t} \quad=$ stochastic error term of firm $i$ at time $t$.

The variables and hypothesized signs are as follows:

\section{(i) Beta or ' $\beta$ et'}

Systematic risk is linked to market whereas unsystematic risk is linked to a single firm (Rowe and Kim, 2010). Systematic risk is defined as beta, which means that stock variability is due to market change or more extensively covariance of the capital market stock returns ( $\mathrm{Gu}$ and Kim, 2002). Beta tests the slope of regression line between the return on the market and expected return on security (Lee and Jang 2002), and mathematically is represented as

$$
\mathrm{R}_{i}=\beta_{o}+\beta_{i} \mathrm{R}_{m}+\mathrm{e}_{i}
$$

Ri indicates a business return which has a linear structure with market return Rm, and ei indicates the disturbances. And beta is determined by following formula via this equition:

$$
\beta_{i}=\operatorname{Cov}(\mathrm{Ri}, \mathrm{Rm}) / \operatorname{Var}(\mathrm{Rm})
$$

Where, $\mathrm{Bi}$ is systematic risk of $i$ th security, $\mathrm{Ri}$ return from $i$ th security and $R \mathrm{~m}$ is market return. Logue and Merville (1972) argued that the predicted beta is closed to the true beta, but is not measurable. Logue and Merville (1972) concluded that the expected beta is a reasonable level of systematic risk since it depends on all matters in which companies can be affiliated.

\section{(ii) Size or SIZ}

'SIZE is the size of the company ' $i$ ' in period ' $t$ '. The size is determined by the formula of total assets of the company. Total assets are translated into natural logarithms of total assets, taking into account the impact of skewness (Iqbal and Shah (2011). According to 
the studies performed by Logue and Merville (1972), Breen and Lerner (1973), Titman and Wessels (1988), Gu and Kim (2002), and Olib et al. (2008), it is hypothesized that stock beta is negatively linked to the company's total assets.

\section{(iii) Leverage or LEV}

LEV is the leverage of company ' $i$ ' in period ' $t$ '. Leverage reflects the financial position of a company and assists the investors in assessing company's risk level. The formula of financial ratio employed to determine the leverage of companies is debt ratio which is total debt to total assets. This defines a company's debt level in relation to its assets, along with the possible risks posed by the company in terms of its debt-load. Total debt contains short and long-term loans or financing from financial institutions, debenture/bonds, deferred payment arrangements for buying capital equipment, interest bearing public deposits, and any other interest-bearing loans. It is hypothesized from the studies of Amit and Livnat (1988), Kim et al. (2002), Lee and Jang (2007), Hong and Sarkar (2007), Olib et al. (2008), and Ramadan (2012) that there is a positive relationship between leverage and beta. High leverage means the company acquires more debt exposing it to possibility of bankruptcy. So it indicates a positive beta relationship.

\section{(iv) Profitability or PRO}

ROA is return on assets of company ' $i$ ' in period ' $t$ ' which is net income to total assets. The profitability of the firm is reflected via ROA. High productivity companies are more robust and thus minimizing systemic risk. It is hypothesized, based on studies by Logue and Merville (1972), Scherrer and Mathison (1996), Borde (1998), Gu and Kim (2002), Lee and Jang (2007), and Rowe and Kim (2010), that there is a negative interaction between asset returns and beta.

\section{(v) Growth or GRO}

GRO is the growth of company ' $\mathrm{i}$ ' in period ' $\mathrm{t}$ '. This is the difference in earning before interest and taxes for the company. Annual percentage change in EBIT helps to measure the company's growth. Rapidly rising companies, often calculated with growth in asset and sales, are also seen as vulnerable to economic change. It is hypothesized on the basis of Borde (1998), Gu and Kim (2002), Roh (2002), and Lee and Jang (2007) that there is a positive relationship between systematic risk and company development.

\section{(vi) Operating Efficiency or EFI}

EFI is operating efficiency of company ' $i$ ' in period ' $t$ '.It is the net revenue or profits over total assets or turnover of assets. The operation efficiency of the under review companies is calculated by the total turnover ratio of assets which indicate the amount of revenue generated from each of assets . Total revenue comprises of income from interest, discount and commission, other operating income, unusual transaction income, rebate, other income, and provision refund. Firms that are very effective in earning income from their assets will have higher probability to be profitable. The empirical studies show that companies that very efficient with their assets in making income are more likely to incur losses and therefore could have a low level of systemic risk. The hypothesis is the negative relation between operational efficiency and systemic risk, 
based on studies by Logue and Merville (1972), Borde (1998), Gu and Kim (1998, 2002), Eldomiaty et al. (2009).

\section{Unit Root Test}

Unit root tests are tests for stationarity in a time series. Stationarity occur in time series when a shift in time doesn't cause a change in the shape of the distribution and unit roots are one cause for non-stationarity. This is important to examine the unit root problem to avoid any statistical problem and biased conclusion. Levin, Lin \& Chu Test (LLC), used to check the unit root problem. The unit root hypotheses as below:

$\mathrm{H}_{\mathrm{o}}$ : The data is not stationary and has a unit root

$\mathrm{H}_{1}$ : The data is stationary and has no unit root

Table 1: Unit Root Test

\begin{tabular}{|c|c|c|c|c|c|}
\hline \multirow[b]{2}{*}{ Variables } & \multicolumn{3}{|c|}{ At Level } & \multicolumn{2}{|c|}{ First Difference } \\
\hline & Test & No Trend & With Trend & No Trend & With Trend \\
\hline \multirow[t]{4}{*}{ BETA } & LLC & $0.0000 * * *$ & & & \\
\hline & IPS & $0.0000 * * *$ & & & \\
\hline & $\mathrm{ADF}$ & $0.0008 * * *$ & & & \\
\hline & PP & $0.0013 * * *$ & & & \\
\hline \multirow[t]{5}{*}{ SIZE } & LLC & 0.4321 & 0.5547 & 0.3757 & $0.0000 * * *$ \\
\hline & IPS & 0.9896 & 0.7565 & 0.2837 & 0.4548 \\
\hline & $\mathrm{ADF}$ & 0.9616 & 0.8916 & 0.3349 & $0.0590 * *$ \\
\hline & PP & 0.1624 & $0.0000 * * *$ & $0.0000 * * *$ & $0.0002 * * *$ \\
\hline & BTT & & 0.8057 & & 0.9806 \\
\hline \multirow[t]{5}{*}{ LIQ } & LLC & $0.0071 * *$ & $0.0000^{* * *}$ & $0.0000 * * *$ & \\
\hline & IPS & 0.3076 & 0.2144 & $0.0000 * * *$ & \\
\hline & $\mathrm{ADF}$ & 0.1598 & $0.0734 *$ & $0.0000 * * *$ & \\
\hline & $\mathrm{PP}$ & $0.0075 * *$ & $0.0001 * * *$ & $0.0000 * * *$ & \\
\hline & BTT & & $0.0888^{*}$ & & \\
\hline \multirow[t]{5}{*}{ PRF } & LLC & 0.3250 & $0.0018 * * *$ & $0.0002 * * *$ & \\
\hline & IPS & 0.3486 & 0.7700 & $0.0032 * * *$ & \\
\hline & $\mathrm{ADF}$ & $0.0585^{* *}$ & 0.5145 & 0.1290 & \\
\hline & $\mathrm{PP}$ & 0.5507 & 0.7690 & $0.0004 * * *$ & \\
\hline & BTT & & 0.9998 & & \\
\hline \multirow[t]{5}{*}{ LEV } & LLC & 0.2135 & $0.0094 * * *$ & & \\
\hline & IPS & 0.5387 & 0.5917 & & \\
\hline & $\mathrm{ADF}$ & 0.5432 & 0.6814 & & \\
\hline & PP & $0.0336 * *$ & $0.0060 * * *$ & & \\
\hline & BTT & & $0.0953 *$ & & \\
\hline \multirow[t]{5}{*}{ GRW } & LLC & $0.0000 * * *$ & & & \\
\hline & IPS & $0.0037 * * *$ & & & \\
\hline & $\mathrm{ADF}$ & $0.0040 * * *$ & & & \\
\hline & PP & $0.0000 * * *$ & & & \\
\hline & BTT & & & & \\
\hline \multirow[t]{5}{*}{$\mathrm{EFF}$} & LLC & 0.7835 & $0.0052 * * *$ & $0.0000 * * *$ & \\
\hline & IPS & 0.9035 & 0.7070 & $0.0345 * *$ & \\
\hline & $\mathrm{ADF}$ & 0.7218 & 0.5651 & $0.0080 * * *$ & \\
\hline & PP & $0.0479 * *$ & $0.0221 * *$ & $0.0000 * * *$ & \\
\hline & BTT & & 0.9983 & & \\
\hline
\end{tabular}

Note: $*, * *$ and $* * *$ indicate significance at $10 \%, 5 \%$ and $1 \%$ 
The results of the unit root test obtained disclose that BETA and GRW failed to accept null hypotheses at level whereas SIZE, LIQ, PRF and EFF reject the null hypotheses at 1st difference level. Thus, the variables did not have the stationary problem.

Descriptive analysis

Table 2: Descriptive statistic

\begin{tabular}{lrrrrrrr}
\hline & \multicolumn{1}{l}{ Mean } & \multicolumn{1}{l}{ Max } & \multicolumn{1}{l}{ Min } & $\begin{array}{c}\text { Std. } \\
\text { Deviation }\end{array}$ & N & Skewness & Kurtosis \\
\hline Beta & 0.78 & 1.7542 & -3.2850 & 1.45 & 440 & .2539 & 14.7 \\
Size & 13.4 & .2797 & .0547 & .529 & 440 & .2139 & 22.1 \\
Leverage & 0.45 & .9895 & .7650 & .1389 & 440 & -.7029 & 3.651 \\
Profitability & 0.041 & 0.34 & -0.145 & 0.412 & 440 & -5234 & 44.432 \\
Growth & 0.06 & 0.38 & -0.125 & 0.231 & 440 & -653 & 122.97 \\
Liquidity & 2.541 & .9979 & .0802 & .1513 & 440 & 3.4230 & 51.4 \\
Operating & 0.438 & 3.73 & 0.0076 & 0.324 & 440 & 1.23 & 43.9 \\
Efficiency & & & & & & &
\end{tabular}

Table 2 exhibits the descriptive information of beta (systemic risk) and five independent variables for 80 shariah compliant listed companies for 9 years period from 2009 to 2018. Unit root test has been conducted and the result shows no issue of stationary. As such, the time series regession is valid. Regression is done by fixed effect model (after doing the testing) which addresed the issue of outliers data. The data shows that the value of systematic risk / beta is 0.75 (mean). This indicates shariah compliant firms are less risky than market beta that is always considered equal to 1 . Similarly, size has a mean score of 13.4 with standard deviation of 0.529 . Arithmetic means of return on assets, growth, liquidity and efficiency are $0.041,0.06,2.54$ and 0.438 respectively.

Choosing the best model

\section{a) Likelihood Ratio Test}

Likelihood Ratio Test is conducted to choose the best model between Pooled Ordinary Least Squares(POLS) model and Fixed Effects model. The hypotheses statements are:

$H_{0}$ : POLS model is preferred.

$H_{1}$ : Fixed Effects model is preferred

Table 3 : Likelihood Ratio Test Statistics (P-Value)

\begin{tabular}{cc}
\hline Effects Test & $\begin{array}{c}\text { Shariah Compliant } \\
\text { Companies }\end{array}$ \\
Cross-section F & 3.786634 \\
& $(0.0000)^{* * *}$ \\
Cross-section & 139.508856 \\
Chi-square & $(0.0000)^{* * *}$ \\
\hline
\end{tabular}




\section{b) Hausman Test}

There are two types of panel regression models that may be used which are Fixed Effects model and Random Effects model. Since the Likelihood Ratio Test indicates that Fixed Effects model is preferred, next the Hausman Test must be conducted to further choose between these 2 panel regression models. The hypothesis statements are:

$H_{0}$ : Random Effects model is preferred.

$H_{1}$ : Fixed Effects model is preferred.

Table 4 : Hausman Test Statistics

\begin{tabular}{cc}
\hline Test Summary & Shariah Compliant \\
& Companies \\
Cross-section random & 20.167052 \\
& $(0.0097)^{* * *}$ \\
\hline
\end{tabular}

Null hypothesis is rejected, and it can be concluded that Fixed Effects model is preferred.

Table 5 : Regression analysis

\begin{tabular}{lllll}
\hline & Coefficients & $\begin{array}{l}\text { Standard } \\
\text { Errors }\end{array}$ & t stat & $\boldsymbol{p}$-value \\
\hline (Constant) & 0.213 & .0543 & 7.613 & $.000^{* * *}$ \\
Size & -0.421 & .234 & -4.192 & $.536^{* *}$ \\
Leverage & 0.8683 & 1.98 & 1.765 & $.003^{* * *}$ \\
Profitability & -0.304 & 4.11 & -4.321 & $0.05^{* *}$ \\
Growth & 0.421 & 12.11 & 2.12 & $0.000^{* * *}$ \\
LIQD & -.271 & 0.087 & -12.071 & $.000^{* * *}$ \\
Efficiency & -0.012 & 8.12 & -4.54 & 0.065 \\
R Square & 0.3605 & & Standard & 0.7181 \\
Adjusted & 0.3548 & & Error & \\
R Square & 19.2858 & & & \\
F & & & F stat Sig & $0.0000^{* * *}$ \\
Durbin & 1.561 & & \\
Watson & Note: $* * *, * *$ denote significance at $1 \%, 5 \%$ respectively
\end{tabular}

\section{RESULTS AND DISCUSSION}

Based on the findings, size, profitability, liquidity and efficiency have negative relationship systemic risk respectively. The results are in line with the earlier hypothesis. As the size, profit and liquidity increase, the firms are expected to be more resilient towards systematic risk, which brings to its negative relationship. This is compatible with the Logue and Merville (1972), Breen and Lerner (1973), Titman and Wessels (1988), Gu and Kim (2002), and Olib et al. (2008) studies. For the relationship between systemic risk to growth and leverage, both of the variables have positive relationship with systematic risk. The findings are also in line with in line with theory that advocate higher level of leverage causes to higher systematic risk. Meanwhile, high growth firms, are often considered vulnerable to economic modifications. 
The findings, thus, partly move in line with the theoretical aspects of finance and empirical evidences of developed and emerging stock markets. The conclusion resulting from this study is that systemic risk is significantly determined by financial characteristics of the listed company. The results demonstrate that company's leverage and growth are the most major factors of the systematic risk of Shariah compliant firms. As such, high leverage and growth firms are considered to be very risky for investment.

In order to determine whether the Fixed Effects model fits the data well, a Model Fit Test was conducted. The F-statistics generated for Shariah compliant companies is 3.786, with p-value of 0.0000 . The p-value was less than $\alpha=0.01$, meaning that the Fixed Effects model was significant at $1 \%$ and fits the sample data well. The adjusted R-squared value was 0.355 , which indicates that $35 \%$ of the variation in systematic risk of Shariah compliant companies can be explained by the selected independent variables.

\section{CONCLUSION AND RECOMMENDATIONS}

One of the most important objectives of a company is to maximize profits for its stakeholders. Therefore, one of the endeavors to maximize return is by decreasing the firm's portion of risk. Considering the significant affect of systematic risk, it is essential to examine various aspects of systematic risk - especially from Malaysia and shariah compliant firms' perspective where sufficient works exist on the subject matter. This studies choosed firms listed on Bursa Malaysia as a sample under review, for the timeframe of the year 2009 to 2018. Six factors of the determinants (explanatory variables) were established and hypothesis were constructed based on existing literatures.

Some important findings can be conclude by shariah compliant companies listed on Bursa Malaysia from this study, firstly systematic risk can be reduced by improving firms' profitability, size and liquidity position respectively. Secondly, revenue diversification is very essential to minimize beta. It can be established that by acknowledging and knowing these factors, the behavior of systematic risk cannot only be recognized but will also lead to better guideline on proper strategies to reduce it. As such, comprehensive understanding of causes correlated to systematic risk is very important for investors and financial policy makers. Investor's prospects are vital and financial policy makers should take them into account at the time of policy making.

This study is having good prospects for future research by inclusion of other accounting variables, or scope of this study can be extended to the whole companies rather than only selected one. Subject to the availability of data, increasing the time duration under study for more years can be a prospective continuation in this regard to produce more substantial results. In addition, the findings relied on quantitative analysis (regressions) which is insufficient for a rich. Therefore, more qualitative analysis is required (interviews with key decision-makers) to understand the position of systematic risk relationship.

\section{REFERENCES}

Beaver, W. \& Manegold, J. (1975). The association between market-determined and accountingdetermined measures of systematic risk: Some further evidence. Journal of Financial and Quantitative analysis, 231-284. 
Biase \& D“Apolito. (2012). The determinants of systematic risk in the Italian banking system: A cross-sectional time series analysis, International Journal of Economics and Finance, 4(22), 152-164.

Bildersee, J. (1975). The association between a market-determined measure of risk and alternative measures of risk. The Accounting Review, 81-98.

Bolster, Paul J. and Janjigian, V. (1991). Dividend policy and valuation effects of the tax reform Act of 1996, National Tax Journal, 44(4), Part 2, 511-518.

Borde, S.F. (1998). Risk diversity across restaurants, Cornell and Hotel Quarterly and Restaurant Administration Quarterly, 39(6), 64-69.

Bowman, R.G. (1979). The theoretical relationship between systematic risk and financial (accounting) variables, Journal of Finance, 34(3), 617-630.

Breen, J., \& Lerner, M. (1973). Corporate financial strategies and market measures of risk and return. The Journal of Finance, 28(2), 339-351.

Chen, N. F., Roll, R. \& Ross, S. A. (1986). Economic forces and the stock market, Journal of Business, 59, 383-403.

Chiou, C. C., \& Su, R. K. (2007). On the relation of systematic risk and accounting variables. Managerial Finance, 33(8), 517-533.

De Jong, D.V. \& Collins, D.W. (1985). Explanations for the instability of equity beta: Risk free rate changes and leverage effects, Journal of Financial and Quantitative Analysis, 20, 73-94.

Eldomiaty, I.T., Mariam H. Al Dhahery, \& Shukri, Muna A. (2009). The fundamental determinants of systematic risk and financial transparency in the DFM General Indux, Middle Eastern Finance and Economics, 5, 62-74.

Graham, Benjamin \& Dodd, David L. (1951). Security Analysis: Principles and Techniques, 3rd edition, New York: McGraw-Hill Book Co.

Gu, Z. \& Kim, H.(1998). Casino firms' risk features and their beta determinants. Progress in Tourism and Hospitality Research, 4, 357-365.

Gu, Z. \& Kim, H. (2002). Determinants of restaurant systematic risk: A re examination. The Journal of Hospitality Financial Management, 10(1),1-13.

Gujarati, Damodar N. \& Porter, Dawn C. (2009). Basic Econometrics. 5th edition, New York: McGrew-Hill/Irwin, a business unit of The McGraw-Hill Companies.

Hong, G., \& Sarkar, S. (2007). Equity systemic risk (Beta) and its determinants. Contemporary Accounting research, 24(2), 423-466.

Hooy, C. W., \& Lee, C. H. (2012). Determinants of systematic financial risk exposures of airlines in North America, Europe and Asia. Journal of Air Transport Management , 34, 31-35.

Iqball, Muhammad Junaid \& Shah, A. (2011). Determinants of systemic risk, The Journal of Commerce,4(1), 47-56.

Hamada, R. S. (1972). The effect of the firm's capital structure on the systematic risk of common stocks. The Journal of Finance, 27(2), 435-452.

Husin, N., \& Wong, M. F. (2016). The effects of credit rating announcements on stock performance in Malaysia. Specialty Journal of Accounting and Economics , 2(1), 77-90. 
Ibrahim, K., \& Haron, R. (2016). Examining systematic risk on malaysian firms: Panel data evidence. Journal of Global Business and Social Entrepreneurship , 1(2), 26-30.

Ismail, A. G. (2010). Money, Islamic Banks and The Real Economy. Singapore: Cengage Learning Asia Pte Ltd.

Khan, Ather Azim \& Iqbal, K. (2012). Dividend policy and stock prices, SAICON, Lahore: COMSATS Institute of Information Technology.

Kim, H., Z., Gu \& Mattila, A.S. (2002). Hotel real estate investment trusts' risk features and beta determinants. Journal of Hospitality and Tourism Research, 26(2), 138-154.

Kumar V., Rahman A., \& Ali A.,(2015) The determinants of systematic risk: Empirical evidence from pakistan's banking sector. Journal of The Global Management Journal for Academic \& Corporate Studies, 1, 142-150

Lee, C., \& Brewer, E. (1985). The association between bank stock market-based risk measures and the financial characteristics of the firm: A pooled cross-section time series approach. Federal Reserve Bank of Chicago Proceedings, 285-315.

Lee, J.S. \& Jang, S.C.S. (2007). The systematic risk determinants of the US airline industry, Tourism Management, 28, 434-442.

Lev, B. \& Kunitzky, S. (1974). On the association between smoothing measures and the risk of common stock, Accounting Review, 259-270.

Logue, L. \& Merville, J. (1972). Financial policy and market expectations, Financial Management $1(3), 37-44$.

Ludvigsona S. C. \& Ng, S. (2007). The empirical risk-return relation: A factor analysis approach. Journal of Financial Economics, 83, 171-222.

Malkiel, B. (2003). The efficient market hypothesis and its critics. CEPS, Working Paper, 91.

Mandelker, G. N. \& Rhee, S.G. (1984). The impact of degrees of operating and financial leverage on systematic risk of common stock, Journal of Financial and Quantitative Analysis, 19, 45-58.

Mear, R. \& Firth, M. (1988). Risk perceptions of financial analysts and the use of market and accounting data, Accounting and Business Research, 18(72), 335-340.

Rafique, M. (2012). Factors affecting dividend payout: Evidence from listed non-financial firms of Karachi Stock Exchange, Business Management Dynamics, 1(11), 76-92.

Ramadan, Zeyad S. (2012). Does leverage always mean risk? Evidence from ASE, International Journal of Economics and Finance, 4(12), 150-158.

Rowe, T. \& Kim, J. (2010). Analyzing the relationship between systematic risk and financial variables in the casino industry. UNLV Gaming and Research Journal, 12(2), 47-58.

Schemer, P. S. \& Mathison, T. J. (1996). Investment strategies for REIT investors. Real Estate Review, 26(I), 5-10.

Tellis, G. \& Johnson, J. (2007). The value of quality, Marketing Science, 26(6), 758-773.

Titman, S. and Wessels, R. (1988). The determinants of capital structure choice. The Journal of finance, 43(1), 1-19. 